\title{
Antibodies to germinating and yeast cells of Candida albicans in human and rabbit sera
}

\author{
Y. M. HO, MUN H. NG, AND C. T. HUANG \\ From the Department of Microbiology, University of Hong Kong, Pathology Building, Queen Mary \\ Hospital Compound, Hong Kong
}

SUMMARY Two major antigenic components, I and II, were detected by double immunodiffusion in sonic extracts of the germinating $(G)$ or yeast $(\mathrm{Y})$ cells of the dimorphic organism, Candida albicans group A. Component I may be a heterogeneous mixture of antigens which are stable to heating and phenol. Component II is more homogeneous but is labile to heat and phenol.

Rabbit antisera, showing only precipitin to component II or certain human sera at high dilution, were found to react with $G$ cells to give an immunofluorescence which was confined to the germ tubes. This suggested that component II is localised on the germ tubes, whereas no immunofluorescent reaction against the yeast cells could be detected under the same conditions although component II was as readily extracted from these cells as from $G$ cells. This suggested that component II might exist in a cryptic state in the $Y$ cells. In support of the latter contention it was shown that live $Y$ cells did not absorb precipitin to component II nor were they capable of providing these antibodies in rabbits.

Using both human and rabbit sera, it was shown that the antigenic specificity of the immunofluorescence assay where $Y$ cells were used was related to component I and that where G cells were used it was related to both components I and II.

Opportunistic infection with Candida albicans is becoming increasingly prevalent, particularly among patients who are compromised immunologically or otherwise (Bodey, 1966; Hart et al., 1969; Ashcraft and Leape, 1970; Ho et al., 1977). An efficient method for its diagnosis is still lacking, however. In an earlier report (Ho et al., 1976) we obtained sera from healthy subjects and patients who showed clinical and mycological evidence of candidiasis. The sera were tested for indirect immunofluorescence (IF) against the yeast (Y) and germinating (G) cells of the dimorphic organism, C. albicans group A, which are known to differ with respect to their antigens and chemical composition (Chattaway et al., 1968; Evans et al., 1973; Syverson et al., 1975). It was found that the patients generally had significantly higher serum antibody titres than the healthy subjects and that the IF reaction against $G$ cells observed with many of the patients' sera at high dilution was confined to the germ tubes. These findings are compatible with an extensive mycelial infiltration observed in sections of tissue infected

Received for publication 16 October 1978 with this organism (Winner, 1969) and suggest that the immunofluorescence assay might be a useful diagnostic aid in candidiasis.

We report the results of further studies in which we sought to define the antigenic specificity of the immunofluorescence assays by comparing the IF titres with precipitating antibodies to $C$. albicans using human sera and rabbit antisera produced against $\mathrm{Y}$ and $\mathrm{G}$ cells of $C$. albicans group $\mathrm{A}$.

\section{Material and methods}

PATIENTS

Serum specimens were obtained from 33 patients among whom were 10 with carcinoma of the oesophagus, two each with carcinoma of the stomach, colon, and liver respectively, one each with carcinoma of the bladder, lung, and bronchus, and two patients with leukaemia. Nine of the patients with carcinoma of the oesophagus and the two with carcinoma of the colon were on hyperalimentation. Two additional patients were on hyperalimentation, one with intestinal obstruction and one with a choledochal cyst. The remaining 
patients included those with status asthmaticus, neurogenic bladder, malformation of the urinary tract, lung abscess, hepatosplenomegaly, monilia infection of the perineum, and burns. These patients had been routinely investigated mycologically and serologically (see Appendix, p. 404).

HUMAN SERA

Serum specimens were obtained from the 33 patients within two weeks of the positive culture of C.albicans group A. These, along with sera collected from 25 healthy subjects, were stored at $-20^{\circ} \mathrm{C}$ until used.

\section{ORGANISMS}

C. albicans group A was inoculated onto Sabouraud agar. After 48 hours' incubation at $37^{\circ} \mathrm{C}$ the growth was scraped off, washed, and resuspended in distilled water. Under these cultural conditions, the growth was made up predominantly of the $\mathrm{Y}$ form.

To obtain $G$ cells, the organism was inoculated into $1 \%$ mycological peptone (Difco, US) supplemented with $0.2 \%$ glucose, according to Evans et al. (1975). Cultures were shaken at $40^{\circ} \mathrm{C}$ for 2 to 3 hours. The cultures were harvested by centrifugation and the resulting $G$ cells were washed with and resuspended in saline.

IMMUNOFLUORESCENCE ASSAY

IF assays were performed as described by Ho et al. (1976). Serially diluted sera were allowed to react with acetone-fixed smears of $G$ cells or $Y$ cells for one hour. The smears were washed and incubated for one additional hour with fluorescein conjugated (FITC) anti-human immunoglobulin (1:16 diluted, Hyland, US) or FITC anti-rabbit immunoglobulin (1:16 diluted, Wellcome, UK). The titre IF-G or IF - Y was expressed as the reciprocal of the maximum serum dilution that gave a positive IF reaction.

IMMUNISATION

Suspensions of live $\mathrm{G}$ or $\mathrm{Y}$ cells containg $1 \times 10^{6}$ organisms per $\mathrm{ml}$ were given intravenously to New Zealand white rabbits at weekly intervals. Animals were test-bled on the third day after the fourth injection by the IF assays. Larger quantities of blood were obtained by heart puncture. Heatkilled suspensions of $Y$ and $G$ cells, prepared by heating live suspensions at $65^{\circ} \mathrm{C}$ for 6 hours, were used to immunise rabbits as well.

EXTRACTS

$Y$ or $G$ cells washed and packed before or after heat treatment were suspended in an equal volume of saline for extraction. To prepare sonic extracts, the suspensions were subjected to ultrasonication with a Branson sonifier at maximum output for 35 minutes. Sonication was carried out at 2-minute intervals with rests at $4{ }^{\circ} \mathrm{C}$. The sonicates $(\mathrm{Y}$ and $\mathrm{G})$ were clarified by centrifugation at $12000 \mathrm{~g}$ for 30 minutes.

Phenol extracts ( $Y p$ and $G p)$ were prepared by mixing a suspension of $C$. albicans with equal volumes of phenol. The mixtures were vigorously shaken for 30 minutes at room temperature and centrifuged, and the aqueous layers were aspirated and dialysed extensively against distilled water and saline. The extracts were then clarified by centrifugation at $12000 \mathrm{~g}$ for 30 minutes.

\section{DOUBLE IMMUNODIFFUSION}

Double immunodiffusion was performed at room temperature in $1 \%$ agarose made up in $0.1 \mathrm{M} \mathrm{NaCl}$.

\section{AGGLUTINATION TEST}

Serially diluted aliquots of sera were mixed with an equal volume of a yeast cell suspension containing $3 \times 10^{6}$ cells per $\mathrm{ml}$ of saline. The mixtures were incubated at $37^{\circ} \mathrm{C}$ for 2 hours and then allowed to stand at $4 \mathrm{C}$ overnight. Agglutinin titre is the reciprocal of the maximum serum dilution giving a positive agglutination.

\section{Results}

PRECIPITATING ANTIBODIES IN RABBIT AND HUMAN SERA

Rabbit antisera were produced against live $G$ or $Y$ cells of $C$. albicans. These antisera, anti-G and anti$\mathrm{Y}$, were tested by double immunodiffusion against a sonic extract of $G$ cells (Fig. 1). Both antisera

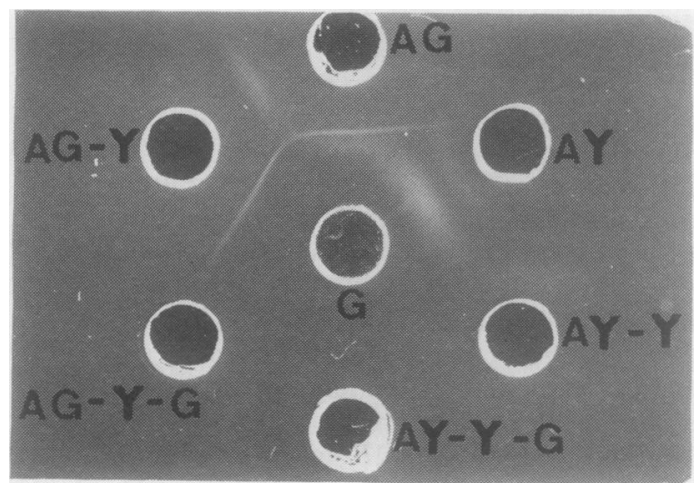

Fig. 1 Double immunodiffusion patterns of rabbit sera against a sonic extract of live $G$ cells $(G)$. The antisera included anti- $Y(A Y)$, anti-G $(A G)$, and the same antisera which had been exhaustively absorbed with $Y$ cells ( $A Y-Y ; A G-Y)$ or with $Y$ cells followed by $G$ cells $(A Y-Y-G ; A G-Y-G)$. 
reacted to give a diffused zone of precipitate probably due to a heterogeneous mixture of antigens referred to hereafter as component I. In addition, anti-G, but not anti-Y, gave a well-defined line of precipitate, and the corresponding antigen is referred to as component II. A third antigenic component (component III) was detected using anti-Y, but this antigen was not consistently resolved in subsequent analysis.

The rabbit antisera were exhaustively absorbed with live $Y$ or $G$ cells and then similarly tested. It was shown that precipitin to component I may be absorbed with either type of cells while absorption of precipitin to component II could be effected with live $G$ cells only. The precipitation line observed between the antisera wells in Fig. 1 was probably

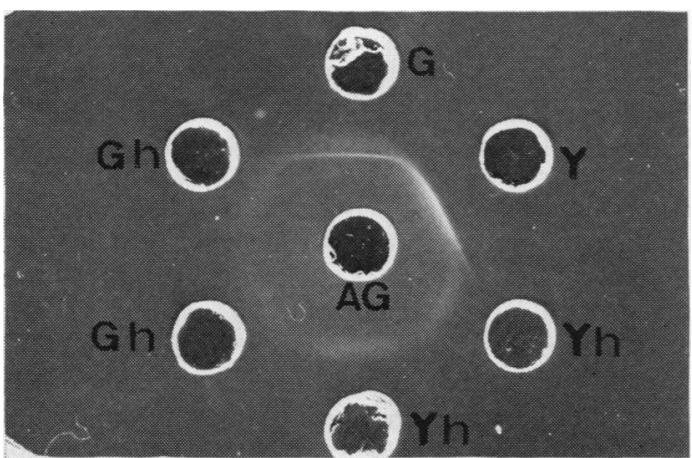

Fig. 2 Double immunodiffusion patterns of rabbit antiserum to live $G$ cells $(A G)$ against sonic extracts of live or heat-killed $G$ cells $(G$ and $G h)$ or of $Y$ cells $(Y$ and $Y h)$.

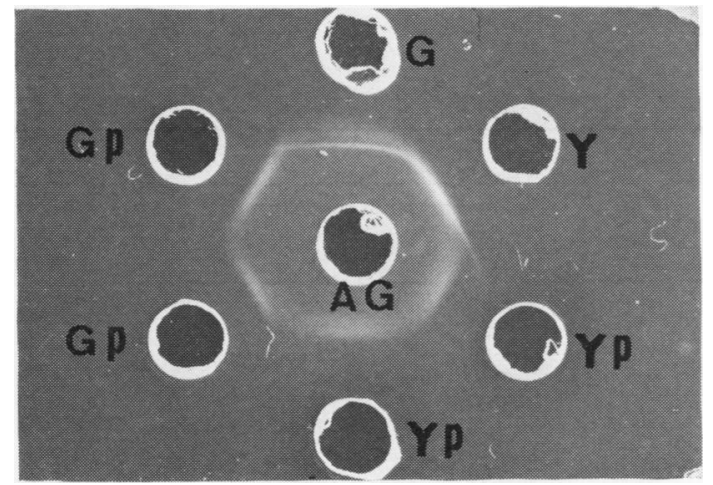

Fig. 3 Double immunodiffusion patterns of rabbit antiserum to live $G$ cells $(A G)$ against sonic or phenol extracts of live $G$ cells $(G$ and $G p)$ or live $Y$ cells $(Y$ and $Y p)$.

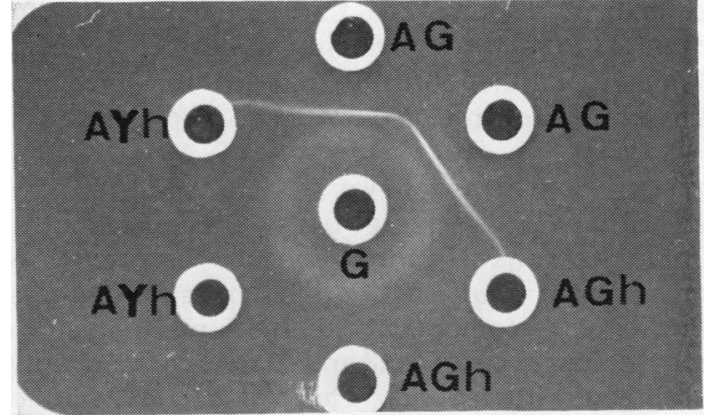

Fig. 4 Double immunodiffusion patterns of rabbit sera against a sonic extract of live $G$ cells $(G)$. The antisera were; $A G$, antisera against heat-killed $G$ cells $(A G h)$ and $Y$ cells $(A Y h)$.

due to residual antigens present in the absorbed sera.

Figures 2 and 3 show the immunodiffusion patterns obtained by reacting anti-G against different extracts of $Y$ and $G$ cells. Component I was detected in all extracts tested, whereas component II, which appeared to be labile to heating and phenol, was detected only in the sonic extracts of live $G$ and $Y$ cells.

In Fig. 4, rabbit antisera produced against live or heat-killed organisms were tested against a sonic extract of $G$ cells. All the antisera tested were reactive against component $I$ but only anti-G contained antibodies to component II. It seems that component II, although extractable from $\mathbf{Y}$ cells (see Fig. 2), might exist in a cryptic state in these cells, and, as such, $Y$ cells are neither capable of producing antibodies to component II nor of absorbing these antibodies (see Fig. 1). Thus component II is distinct from the mycelial specific antigens observed by other investigators (Syverson et al., 1975), and, probably because of limited resolution of the present technique, phase specific antigens were not observed.

Thirty-three patients were investigated serologically and mycologically. The results of these investigations and the primary clinical symptoms of these patients are shown in the Appendix. Precipitating antibodies to $C$. albicans present in these sera were tested by double immunodiffusion and compared with those formed with rabbit anti-G. Based on the occurrence of the precipitating antibodies, the sera may be divided into four groups, one of which, as exemplified by serum $P_{1}$, reacted with a sonic extract of live $G$ cells to give a line of identity to the reaction between component II and the rabbit anti-G. The second group of sera, an example of which is $\mathrm{P}_{2}$, contained precipitin to 
component I only. The third group of sera, for example $\mathbf{P}_{3}$, showed precipitin to both components $\mathrm{I}$ and II, and the fourth, $\mathrm{P}_{4}$, did not show precipitating antibodies to C. albicans (Fig. 5).

CORRELATION BETWEEN IF REACTIVITIES AND PRECIPITATING ANTIBODIES TO $C$. albicans

Table 1 shows IF titres and the occurrence of precipitin to $C$. albicans in different rabbit antisera. Precipitin to component $I$ and IF reactivity to $Y$ cells present in anti-G and anti- $Y$ were concomitantly absorbed with $\mathrm{Y}$ cells. The residual activities of anti-G after exhaustive absorption with $Y$ cells included precipitin to component II and IF reactivity against $G$ cells, which in turn were concomitantly absorbed with $G$ cells. It should be noted also that the ratio of IF titre as determined against $G$ cells to that against $Y$ cells (IF-G/IF-Y) was higher for anti-G than for anti-Y or for the

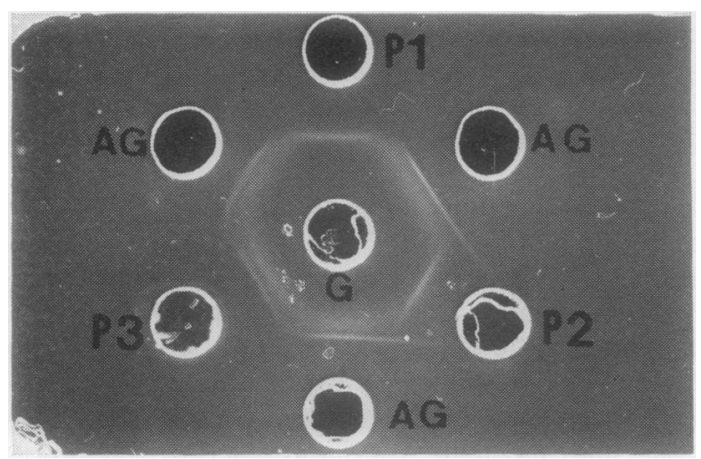

Fig. 5 Double immunodiffusion patterns of patients, sera $\left(P_{1}, P_{2}\right.$ and $\left.P_{3}\right)$ and rabbit serum $(A G)$ against a sonic extract of live $G$ cells $(G)$. antisera produced against heat-killed $Y$ or $G$ cells. A further increase in the ratio was observed after absorption of anti-G with $Y$ cells. It seems from these results that the antigenic specificity of the IF assay where $Y$ cells were used is related to component I while that of the IF assay using $G$ cells is related to both components I and II.

The above conclusion was corroborated by results obtained with human sera. It was shown that the ratio of geometric mean IF titre, as determined against $G$ cells, to that against $Y$ cells (IF-G/IF-Y) was the highest for the group of sera with precipitin to component II only. This was followed by those sera with precipitins to both components I and II. The groups of sera having either precipitin to component I only or no detectable precipitating antibodies also had low values of IF-G/IF-Y (Table 2).

\section{Discussion}

It may be concluded from results obtained with rabbit and human sera that the antigenic specificity of the IF assay using $Y$ cells is related to component I. As judged by the immunoprecipitation pattern, component I probably consisted of a heterogeneous mixture of antigens while their apparent stability to heating and phenol extraction suggests that they are probably polysaccharides. These antigens seem to be shared partly or wholly by both the $G$ and $Y$ cells but we did not attempt further to analyse them by immunological techniques of higher resolution.

The antigenic specificity of the IF assay using $\mathrm{G}$ cells is related to both components I and II. As indicated by the well-defined line of precipitate, component II is more homogeneous than component $\mathrm{I}$. The fact that this antigen is labile to heating and phenol extraction suggests that it is probably of a proteinic nature.

Table 1 Reactivities of rabbit sera against $\mathrm{C}$. albicans

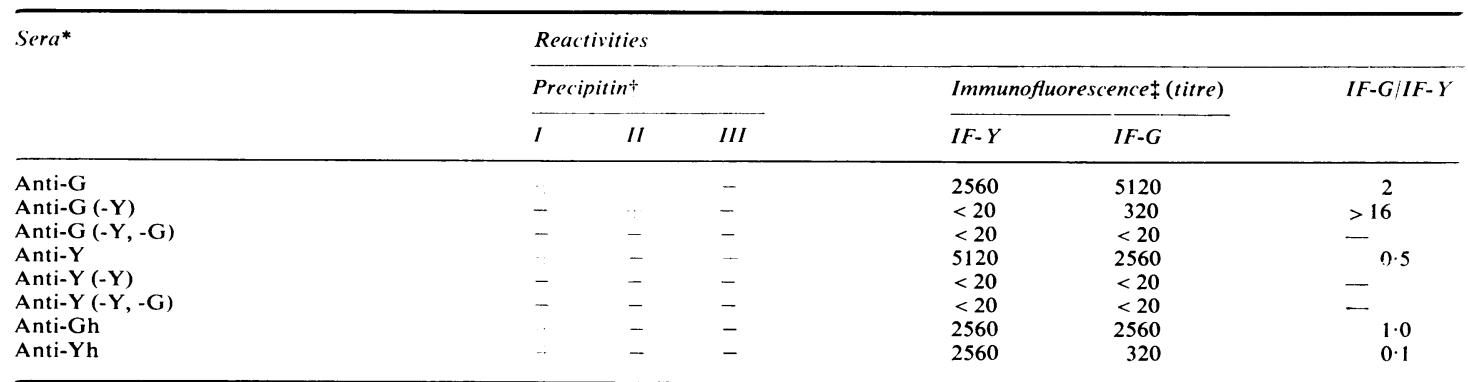

* Hyperimmune rabbit sera were produced against live or heat-killed G cells (anti-G, anti-Gh) or $Y$ cells (anti-Y, anti-Yh). Anti-G and anti-Y were exhaustively absorbed first against $Y$ cells (anti-G $(-Y)$, anti-Y (-Y)) followed by $G$ cells (anti-G- (Y-G), anti-Y (-Y-G)).

+ Precipitating activities of sera were tested by double immunodiffusion against a sonic extract of live $G$ cells.

¥IF-Y and IF-G titres of sera were assayed as described in Material and methods. 
Table 2 Seroreactivities against C. albicans group A in patients and healthy subjects

\begin{tabular}{|c|c|c|c|c|c|}
\hline \multicolumn{2}{|l|}{ Szra } & \multirow{2}{*}{$\begin{array}{l}\text { Precipitating } \\
\text { antibodies } \dagger\end{array}$} & \multicolumn{2}{|c|}{$G M T \ddagger$ (range) } & \multirow[t]{2}{*}{$I F-G / I F-Y$} \\
\hline Source & Number & & $I F-G$ & $I F-Y$ & \\
\hline \multirow[t]{4}{*}{ Patients* } & 7 & I & $\begin{array}{l}1560 \\
(2635-924)\end{array}$ & $\begin{array}{l}640 \\
(1706-240)\end{array}$ & $2 \cdot 44$ \\
\hline & 8 & $\mathbf{I}+\mathbf{I I}$ & $\begin{array}{l}2560 \\
(4863-1348)\end{array}$ & $\begin{array}{l}830 \\
(2537-292)\end{array}$ & $3 \cdot 08$ \\
\hline & 5 & II & $\begin{array}{l}1470 \\
(2626-823)\end{array}$ & $\begin{array}{l}279 \\
(380-204)\end{array}$ & $5 \cdot 27$ \\
\hline & 13 & Negative & $\begin{array}{c}712 \\
(1573-322)\end{array}$ & $\begin{array}{l}245 \\
(477-126)\end{array}$ & 2.91 \\
\hline $\begin{array}{l}\text { Healthy } \\
\text { subjects }\end{array}$ & 25 & Negative & $\begin{array}{c}47 \\
(309-7)\end{array}$ & $\begin{array}{l}59 \\
(334-10)\end{array}$ & $0 \cdot 80$ \\
\hline
\end{tabular}

* Patients as described in Appendix.

†Patients' sera were grouped according to their precipitin against component I complexes and II detected by double immunodiffusion against the sonic extract of germinating cells of $C$. albicans group A.

$\ddagger$ Indirect immunofluorescence titres against acetone-fixed germinating cell (IF-G) and yeast cells (IF-Y) of C. albicans group A observed in individuals in each group were shown as geometric mean titres and ranges.

Table 3 Antibodies to C. albicans group $A^{*}$ in sera obtained from patients and healthy subjects

\begin{tabular}{|c|c|c|c|c|c|c|}
\hline \multicolumn{2}{|l|}{ Sera } & \multicolumn{3}{|c|}{$\begin{array}{l}\text { Geometric mean titres* } \\
\text { (range) }\end{array}$} & \multicolumn{2}{|c|}{$\begin{array}{l}\text { No. of sera* with } \\
\text { precipitins to: }\end{array}$} \\
\hline Subjects & No. & $I F-G$ & $I F-Y$ & Agg & $I$ & II \\
\hline $\begin{array}{l}\text { Patients with repeated positive } \\
\text { blood and/or urine cultures }\end{array}$ & 17 & $\begin{array}{l}2174 \\
(3869-1222)\end{array}$ & $\begin{array}{l}694 \\
(1787-270)\end{array}$ & $\begin{array}{l}188 \\
(510-70)\end{array}$ & 13 & 12 \\
\hline Other patients $\dagger$ & 16 & $\begin{array}{l}761 \\
(1592-364)\end{array}$ & $\begin{array}{l}258 \\
(497-134)\end{array}$ & $\begin{array}{l}104 \\
(192-56)\end{array}$ & 2 & 1 \\
\hline Healthy subjects & 25 & $\begin{array}{l}47 \\
(309-7)\end{array}$ & $\begin{array}{l}59 \\
(334-10)\end{array}$ & $\begin{array}{l}49 \\
(112-21)\end{array}$ & $\mathbf{0}$ & 0 \\
\hline
\end{tabular}

* Serum specimens were tested by indirect immunofluorescence against G cells (IF-G) and Y cells (IF-Y), by agglutination using Y cells (Agg) and by immunodiffusion against components $I$ and II (I and II) present in a sonic extract of G cells.

$\dagger$ The 33 patients described in the Appendix were divided into 17 who gave repeated positive blood and/or urine cultures of C. albicans and 16 who did not.

Neither component I nor component II is a growth phase specific antigen, as both could be extracted by sonic disruption of $Y$ or $G$ cells. However, after exhaustive reaction of anti-G with $Y$ cells, the absorbed serum, which contained precipitin to component II, gave an IF reaction confined to the germ tubes of $\mathbf{G}$ cells. Immunofluorescence confined to the germ tubes was likewise observed with some human sera at high dilution (Ho et al., 1976). It seems that component II is probably localised on the germ tubes. On the other hand, this antigen seems to exist in a cryptic state in $Y$ cells because these cells were not capable of producing antibodies to component II in rabbits, nor were they able to absorb these antibodies despite the fact that component II was as readily extracted from $Y$ cells as from $G$ cells.

If infection with $C$. albicans involves mycelial infiltration, as is supported by histological evidence (Winner, 1969), it may be anticipated that antibody response to component II may be a distinguishing feature of infection. This is supported by our earlier observations that patients who showed mycological and clinical evidence of candidiasis sustained significantly higher titres of IF antibodies to $C$. albicans than healthy subjects. To evaluate further the diagnostic application of antibodies to C. albicans the patients shown in the Appendix were divided into two groups, as in Table 3. All these patients had primary clinical symptoms that are known to predispose them to infection with $C$. albicans (Bodey, 1966; Hart et al., 1969; Ashcraft and Leape, 1970; Ho et al., 1977) but only patients in one of the groups had repeated positive blood and/or urine cultures of $C$. albicans. Although none of those patients is a confirmed case of candidiasis because mycological evidence alone is insufficient to differentiate active infection from the transient presence of these organisms in the blood and/or urine, it seems reasonable to assume that the group of patients who gave repeated positive blood and/or urine cultures were more likely to be infected with C. albicans than the other group of patients. It was of interest therefore that precipitin to components I and II was detected more frequently in the sera from the former group of patients who also showed significantly higher geometric mean titres of anti- 
bodies to this organism. Also shown in this table. were results obtained from 25 healthy subjects, among whom none showed precipitating antibodies, and their mean serum antibody titres were lower than those observed among the patients. The healthy subjects are also the least likely of the three groups to sustain an infection with $C$. albicans.

Thus, in the three groups of subjects, the serological findings seem to be related to the relative susceptibility to infection with C. albicans. It should be noted that these groups of subjects were better separated on the basis of the frequency of precipitating antibodies to $C$. albicans and by their geometric mean titres of serum antibodies, as determined by immunofluorescence against $G$ cells (IF-G). It seems that antibodies to component II may indeed be of diagnostic value in candidiasis.

\section{References}

Ashcraft, K. W., and Leape, L. L. (1970). Candida sepsis complicating parenteral feeding. Journal of the American Medical Association, 212, 454-456.

Bodey, G. P. (1966). Fungal infections complicating acute leukemia. Journal of Chronic Diseases, 19, 667-687.

Chattaway, F. W., Holmes, M. R., and Barlow, A. J. E. (1968). Cell wall composition of the mycelial and blastospore forms of Candida albicans. Journal of General Microbiology, 51, 367-376.
Evans, E. G. V., Odds, F. C., Richardson, M. D., and Holland, K. T. (1975). Optimum conditions for initiation of filamentation in Candida albicans. Canadian Journal of Microbiology, 21, 338-342.

Evans, E. G. V., Richardson, M. D., Odds, F. C., and Holland, K. T. (1973). Relevance of antigenicity of Candida albicans growth phases to diagnosis of systemic candidiasis. British Medical Journal, 4, 86-87.

Hart, P. D., Russell, E., Jr., and Remington, J. S. (1969). The compromised host and infection. II. Deep fungal infection. Journal of Infectious Diseases, 120, 169-191.

Ho, Y. M., Huang, C. T., and Ng, M. H. (1977). The occurrence of Candida in hospital patients and normal subjects. Southeast Asian Journal of Tropical Medicine and Public Health, 8, 525-531.

Ho, Y. M., Ng, M. H., Teoh-Chan, C. H., Yue, P. C. K., and Huang, C. T. (1976). Indirect immunofluorescence assay for antibody to germ tube of Candida albicans -a new diagnostic test. Journal of Clinical Pathology, 29, 1007-1010.

Syverson, R. E., Buckley, H. R., and Campbell, C. C. (1975). Cytoplasmic antigens unique to the mycelial or yeast phase of Candida albicans. Infection and Immunity, 12, 1184-1188.

Winner, H. I. (1969). The transition from commensalism to parasitism. British Journal of Dermatology, 81, Supplement 1, 62-68.

Requests for reprints to: Dr Y. M. Ho, Department of Microbiology, University of Hong Kong, Pathology Building, Queen Mary Hospital Compound, Hong Kong.

Appendix

Clinical, mycological, and serological data on 33 patients

\begin{tabular}{|c|c|c|c|c|c|c|c|c|c|}
\hline \multirow[t]{2}{*}{ Case } & \multirow{2}{*}{$\begin{array}{l}\text { Sexl } \\
\text { Age }\end{array}$} & \multirow{2}{*}{$\begin{array}{l}\text { Primary } \\
\text { clinical } \\
\text { conditions }\end{array}$} & \multicolumn{2}{|c|}{ Positive cultures of C. albicans group $A$} & \multicolumn{2}{|c|}{ Precipitins to: } & \multicolumn{3}{|c|}{ Antibodytitres } \\
\hline & & & Specimen & $\begin{array}{l}\text { No. of positive } \\
\text { cultures }\end{array}$ & $\begin{array}{l}\text { Component } \\
I\end{array}$ & $\begin{array}{l}\text { Component } \\
\text { II }\end{array}$ & $I F-G$ & $I F-Y$ & Agglutination \\
\hline 1 & F62 & $\begin{array}{l}\text { Carcinoma } \\
\text { oesophagus }\end{array}$ & $\begin{array}{l}\text { Mid-stream urine } \\
\text { Catheterised urine }\end{array}$ & $\begin{array}{l}2 \\
2\end{array}$ & $+t_{t}^{2}$ & + i & 1280 & 1280 & 160 \\
\hline 2 & F54 & $\begin{array}{l}\text { Status } \\
\text { asthmaticus }\end{array}$ & $\begin{array}{l}\text { Sputum } \\
\text { Mid-stream urine }\end{array}$ & $\begin{array}{l}2 \\
4\end{array}$ & $+\ldots$ & $+\infty$ & 5120 & 5120 & 160 \\
\hline 3 & FAd & Cirrhosis of liver & Mid-stream urine & 4 & + & + & 5120 & 320 & 320 \\
\hline 4 & M14 & $\begin{array}{l}\text { Neurogenic } \\
\text { bladder }\end{array}$ & Catheterised urine & 5 & + & 4 & 5120 & 2560 & 1280 \\
\hline 5 & F76 & $\begin{array}{l}\text { Carcinoma } \\
\text { oesophagus } \\
\text { (on hyper- } \\
\text { alimentation) }\end{array}$ & $\begin{array}{l}\text { Rectal swab } \\
\text { Blood } \\
\text { Intravenous catheter } \\
\text { tip }\end{array}$ & $\begin{array}{l}3 \\
3 \\
2\end{array}$ & $\begin{array}{l}+ \\
2+1\end{array}$ & + & 2560 & 640 & 80 \\
\hline 6 & M75 & $\begin{array}{l}\text { Carcinoma } \\
\text { bladder }\end{array}$ & $\begin{array}{l}\text { Mid-stream urine } \\
\text { Wound swab } \\
\text { Blood }\end{array}$ & $\begin{array}{l}2 \\
2 \\
1\end{array}$ & + & + & 2560 & 320 & 40 \\
\hline 7 & F56 & $\begin{array}{l}\text { Intestinal } \\
\text { obstruction } \\
\text { (on hyper- } \\
\text { alimentation) }\end{array}$ & $\begin{array}{l}\text { Catheterised urine } \\
\text { Mid-stream urine } \\
\text { Wound swab } \\
\text { Intravenous catheter tip } \\
\text { Nutritive solution from IV drip }\end{array}$ & $\begin{array}{l}3 \\
2 \\
2 \\
2 \\
1\end{array}$ & $\begin{array}{l}+ \\
t \\
t+2\end{array}$ & $\begin{array}{l}4 \\
4 \\
4\end{array}$ & 1280 & 640 & 160 \\
\hline 8 & F13 & $\begin{array}{l}\text { Choledochal } \\
\text { cyst (on } \\
\text { hyper- } \\
\text { alimentation) }\end{array}$ & $\begin{array}{l}\text { Throat swab } \\
\text { Rectal swab } \\
\text { Mid-stream urine } \\
\text { Catheterised urine } \\
\text { Blood } \\
\text { Wound swab }\end{array}$ & $\begin{array}{l}8 \\
5 \\
6 \\
2 \\
2 \\
6\end{array}$ & $\begin{array}{l}+\frac{1}{1} \\
+3\end{array}$ & + & 2560 & 640 & 160 \\
\hline 9 & FAd & $\begin{array}{l}\text { Carcinoma } \\
\text { bronchus }\end{array}$ & Mid-stream urine & 4 & +4 & 41 & 1280 & 320 & 160 \\
\hline
\end{tabular}




\begin{tabular}{|c|c|c|c|c|c|c|c|c|c|}
\hline \multirow[t]{2}{*}{$\overline{\text { Cuse }}$} & \multirow{2}{*}{$\begin{array}{l}\text { Sexl } \\
\text { Age }\end{array}$} & \multirow{2}{*}{$\begin{array}{l}\text { Primary } \\
\text { clinical } \\
\text { conditions }\end{array}$} & \multicolumn{2}{|c|}{ Positive cultures of $\mathrm{C}$. albicans group $A$} & \multicolumn{2}{|c|}{ Precipitins to: } & \multicolumn{3}{|c|}{ Antibody titres } \\
\hline & & & Specimen & $\begin{array}{l}\text { No. of positive } \\
\text { cultures }\end{array}$ & $\begin{array}{l}\text { Component } \\
\text { I }\end{array}$ & $\begin{array}{l}\text { Component } \\
\text { II }\end{array}$ & $I F-G$ & $I F-Y$ & Agglutination \\
\hline 10 & M70 & $\begin{array}{l}\text { Carcinoma } \\
\text { colon, } \\
\text { intestinal } \\
\text { fistula (on } \\
\text { hyper- } \\
\text { alimentation) }\end{array}$ & $\begin{array}{l}\text { Throat swab } \\
\text { Rectal swab } \\
\text { Mid-stream urine } \\
\text { Blood } \\
\text { Wound swab } \\
\text { Nutritive solution from IV drip }\end{array}$ & $\begin{array}{l}3 \\
3 \\
5 \\
1 \\
4 \\
2\end{array}$ & + & - & 2560 & 2560 & 1280 \\
\hline 11 & F62 & $\begin{array}{l}\text { Chronic myeloid } \\
\text { leukaemia, } \\
\text { lung abscess }\end{array}$ & $\begin{array}{l}\text { Sputum } \\
\text { Mid-stream urine }\end{array}$ & $\begin{array}{l}5 \\
2\end{array}$ & + & - & 2560 & 320 & 160 \\
\hline 12 & FAd & Carcinoma lung & Sputum & 6 & + & - & 1280 & 160 & 40 \\
\hline 13 & MAd & $\begin{array}{l}\text { Carcinoma } \\
\text { oesophagus } \\
\text { (on hyper- } \\
\text { alimentation) }\end{array}$ & $\begin{array}{l}\text { Nasal swab } \\
\text { Throat swab } \\
\text { Rectal swab } \\
\text { Mid-stream urine } \\
\text { Blood } \\
\text { Wound swab } \\
\text { Nutritive solution from IV drip }\end{array}$ & $\begin{array}{l}7 \\
2 \\
4 \\
2 \\
1 \\
5 \\
6\end{array}$ & + & - & 1280 & 1280 & 160 \\
\hline 14 & MAd & $\begin{array}{l}\text { Carcinoma } \\
\text { oesophagus (on } \\
\text { hyperalimentation) }\end{array}$ & Wound swab & 1 & + & - & 640 & 640 & 160 \\
\hline 15 & MAd & $\begin{array}{l}\text { Carcinoma } \\
\text { oesophagus (on } \\
\text { hyperalimentation) }\end{array}$ & $\begin{array}{l}\text { Mid-stream urine } \\
\text { Nutritive solution from IV drip }\end{array}$ & $\begin{array}{l}3 \\
4\end{array}$ & + & - & 2560 & 1280 & 640 \\
\hline 16 & M62 & $\begin{array}{l}\text { Drug addict, } \\
\text { lung abscess }\end{array}$ & Sputum & 6 & - & + & 1280 & 320 & 160 \\
\hline 17 & $\mathrm{M} 2 \mathrm{~m}$ & $\begin{array}{l}\text { Malformation of } \\
\text { urinary tract } \\
\text { (posturethal valve) }\end{array}$ & $\begin{array}{l}\text { Catheterised urine } \\
\text { Catheterised urine from } R \text { and } L \\
\text { ureter } \\
\text { Mid-stream urine } \\
\text { Wound swab }\end{array}$ & $\begin{array}{l}8 \\
1 \\
4 \\
2\end{array}$ & - & + & 640 & 160 & 320 \\
\hline 18 & M49 & $\begin{array}{l}\text { Carcinoma } \\
\text { stomach }\end{array}$ & $\begin{array}{l}\text { Rectal swab } \\
\text { Wound swab } \\
\text { Mid-stream urine }\end{array}$ & $\begin{array}{l}2 \\
4 \\
5\end{array}$ & - & + & 2560 & 320 & 80 \\
\hline 19 & MAd & $\begin{array}{l}\text { Carcinoma } \\
\text { oesophagus (on } \\
\text { hyper- } \\
\text { alimentation) }\end{array}$ & $\begin{array}{l}\text { Rectal swab } \\
\text { Blood } \\
\text { Wound swab } \\
\text { Drip site swab } \\
\text { Intravenous catheter tip } \\
\text { Nutritive solution from IV drip }\end{array}$ & $\begin{array}{l}5 \\
2 \\
2 \\
1 \\
1 \\
1\end{array}$ & - & + & 2560 & 320 & 320 \\
\hline 20 & M58 & Carcinoma liver & Peritoneal swab & 1 & - & + & 1280 & 320 & 160 \\
\hline 21 & M45 & Lung abscess & Sputum & 4 & - & - & 320 & 80 & 80 \\
\hline 22 & M50 & $\begin{array}{l}\text { Carcinoma } \\
\text { stomach }\end{array}$ & Mid-stream urine & 1 & - & - & 1280 & 160 & 80 \\
\hline 23 & M29 & Burn & Wound swab & 2 & - & - & 1280 & 320 & 160 \\
\hline 24 & F13 & $\begin{array}{l}\text { Hepato- } \\
\text { splenomegaly }\end{array}$ & Wound swab & 3 & - & - & 1280 & 320 & 80 \\
\hline 25 & M68 & $\begin{array}{l}\text { Carcinoma } \\
\text { oesophagus (on } \\
\text { hyperalimentation) }\end{array}$ & $\begin{array}{l}\text { Intravenous catheter tip } \\
\text { Rectal swab } \\
\text { n) }\end{array}$ & $\begin{array}{l}2 \\
2\end{array}$ & - & - & 2560 & 640 & 40 \\
\hline 26 & F75 & $\begin{array}{l}\text { Carcinoma colon } \\
\text { (on hyper- } \\
\text { alimentation) }\end{array}$ & $\begin{array}{l}\text { Throat swab } \\
\text { Rectal swab } \\
\text { Mid-stream urine } \\
\text { Wound swab }\end{array}$ & $\begin{array}{l}4 \\
4 \\
1 \\
4\end{array}$ & - & - & 640 & 160 & 80 \\
\hline 27 & F76 & $\begin{array}{l}\text { Carcinoma } \\
\text { oesophagus } \\
\text { (on hyper- } \\
\text { alimentation) }\end{array}$ & $\begin{array}{l}\text { Throat swab } \\
\text { Rectal swab } \\
\text { Wound swab }\end{array}$ & $\begin{array}{l}5 \\
1 \\
3\end{array}$ & - & - & 1280 & 640 & 160 \\
\hline 28 & MAd & Carcinoma liver & Skin swab & 1 & - & - & 640 & 320 & 160 \\
\hline 29 & F76 & $\begin{array}{l}\text { Carcinoma } \\
\text { oesophagus (on } \\
\text { hyperalimentation) }\end{array}$ & $\begin{array}{l}\text { Rectal swab } \\
\text { Nutritive solution from IV drip }\end{array}$ & $\begin{array}{l}1 \\
1\end{array}$ & - & - & 320 & 160 & 160 \\
\hline 30 & M69 & $\begin{array}{l}\text { Carcinoma } \\
\text { oesophagus } \\
\text { (on hyper- } \\
\text { alimentation) }\end{array}$ & $\begin{array}{l}\text { Throat swab } \\
\text { Rectal swab } \\
\text { Wound swab }\end{array}$ & $\begin{array}{l}2 \\
2 \\
2\end{array}$ & - & - & 160 & 80 & 40 \\
\hline 31 & FAd & $\begin{array}{l}\text { Carcinoma } \\
\text { oesophagus }\end{array}$ & $\begin{array}{l}\text { Nasal swab } \\
\text { Wound swab }\end{array}$ & $\begin{array}{l}1 \\
1\end{array}$ & - & - & 1280 & 320 & 80 \\
\hline 32 & F30 & $\begin{array}{l}\text { Monilia infection } \\
\text { of perineum }\end{array}$ & Swab from perineum & 2 & - & - & 320 & 320 & 320 \\
\hline 33 & M60 & Faecal fistula & $\begin{array}{l}\text { Nasal swab } \\
\text { Throat swab } \\
\text { Skin swab }\end{array}$ & $\begin{array}{l}1 \\
1 \\
1\end{array}$ & - & - & 640 & 320 & 160 \\
\hline
\end{tabular}

